\title{
Ethical Quandaries in Business: A Study of Ethical Judgment and Ethical Intentions Through the Lens of Rest's (1979) Ethical Reasoning Process
}

\author{
Sumeet Jhamb \\ University of Alaska Anchorage \\ Teresa Stephenson \\ University of Alaska Anchorage \\ Stacy Bibelhauser \\ Western Kentucky University
}

\begin{abstract}
There is some empirical evidence to understand what managers would actually do when faced with ethical conundrums in the workplace, especially when complex business transactions are involved (Fleischman \& Stephenson, 2012; Johnson et al. 2012; Latan, Chiappetta Jabbour, \& Lopes de Sousa Jabbour, 2019; Valentine, Fleischman, \& Godkin, 2018).

The current study expands upon this research by investigating how certain predictor variables influence the ethical reasoning process of accountants, specifically, Ethics Education, Moral Intensity, Teleological Ethical Orientation, Social Desirability Bias, and Perceived Importance of an Ethical Issue (PIE). The dependent variables are ethical judgement and ethical intent (Jones et al. 2003; Johnson et al. 2012).

The results show that having a teleological ethical orientation and greater PIE are both strongly associated with ethical judgment and weakly associated with ethical intention. Additionally, greater moral intensity is weakly associated with ethical judgment and moderately associated with ethical intention. Our participants show nominal social desirability bias when exercising ethical judgment, but a great deal when indicating an ethical intention. Finally, Ethics education does not significantly influence ethical judgement, but it does moderately influence ethical intention.
\end{abstract}

Keywords: ethics, intentions, ethical dilemma, business behaviors, morality, social desirability, education

\section{INTRODUCTION}

Management accounting (hereafter MA) often directly impacts decision-making in organizations and businesses as executives involve internal accountants who provide information, advice, and reports to assist in the decision-making process. Important decisions at the top of the corporate pyramid oftentimes involve ethicality and the need for quick resolutions in terms of both process and time. Interconnected with the challenges of ethical decision-making related to overall organizational goals, individuals working within 
the organization also face ethical decisions on a personal level as they strive to meet work performance goals. Ethical decision-making behaviors of individuals working under tremendous pressure and high expectations are intertwined with, and can impact, the overall organization both positively and negatively. Extant management literature documents specific organizational benefits, such as greater work effort, of setting work performance goals; however, these challenging performance benchmarks can result in undesirable or unethical behavior by subordinates who are faced with meeting these goals (e.g., Locke and Latham, 2019, 2002, 1990; Luft and Shields 2003).

Despite the positive impact of goal setting, using financial goals, such as meeting budget targets, as criteria for performance evaluation commonly causes dysfunctional behaviors in organizations (Hope and Fraser 1997, 2000, 2003; Jensen 2001, 2003; Welsh \& Ordóñez, 2014; Zaal, Jeurissen, \& Groenland, 2019). In particular, the use of goals to set subordinate compensation levels may encourage employees to engage in undesirable behaviors in order to improve the likelihood of achieving targets (e.g., Chow et al. 1988; Healy 1985; Jennergren 1980; Kohn 1993; McNabb and Whitfield 2007; Ordonez et al. 2009; Pfeffer 1998; Schweitzer et al. 2004; Welsh \& Ordóñez, 2014; Young 1985; Zaal, Jeurissen, \& Groenland, 2019). Three specific areas of potentially unethical behaviors in business and MA include setting a target below what the actor believes is achievable (budgetary slack), misrepresentation of performance (falsified reporting), and inappropriate conduct (workplace ethical issues) (Daumoser, Hirsch, \& Sohn, 2018). The predominance of business and accounting ethics studies assessing budget-related issues focus on budgetary slack (e.g., Chow et al. 1988; Daumoser, Hirsch, \& Sohn, 2018; Davis et al. 2006).

Goal setting may also motivate individuals to misrepresent their performance levels. For example, employees at Bausch and Lomb during the 1990s, under pressure to reach sales targets and earnings goals, reported sales that never took place resulting in falsified financial statements (Plunkett and Rouse 1998). More recently, employees at Wells Fargo created over one million phony accounts to improve performance measures - an action that resulted in more than 5,000 employees losing their jobs and fines of \$185 million (Egan, 2016).

Finally, individuals may engage in unethical actions and methods to achieve their goals (Mitchell, Baer, Ambrose, Folger, \& Palmer, 2018). Actions toward customers, such as aggressive behavior or attempting to sell unnecessary services to customers for the purposes of increasing performance evaluations, pecuniary rewards, or organizational status are also unethical (Burns and Kiecker 1995; Pfeffer 1998; Douglas and Wier 2000; Jensen 2003).

Despite the importance of the overall MA process and the ethical pressures and behaviors involved therein, there is surprisingly little empirical evidence of the ethical judgment and intentions to act ethically when engaging in the complex interactions and transactions that are associated with the MA function (Latan, Chiappetta Jabbour, \& Lopes de Sousa Jabbour, 2019). Additionally, we are unaware of any research that investigates whether the new ethics requirements at most business schools has had any effect on the ethical judgments or intentions of individuals involved in work-specific scenarios.

To better understand key business-related ethical dilemmas that often arise in practice, the present study addresses two fundamental ethical issues in business by employing ethicsrelated vignettes that relate to expense reclassification strategies made under stress. Specifically, the vignettes for investigation in this study include an operational expense reclassification to an asset in order to avoid debt covenant noncompliance and expense reclassification from a proposed capital budgeting project to normal operations in order to increase projected internal rates of return (IRR), thus enhancing the chances of receiving project funding.

The current study focuses on the main effects of 1) moral intensity, 2) teleological ethical orientation, 3 ) perceived importance of an ethical issue (PIE), 4) social desirability bias, and 5) ethics education in accounting classes, on two key dependent variables: ethical judgment and ethical intention.

Only a paucity of research involves the misrepresentation of performance. The present study attempts to add to this literature. The base scenarios address misrepresentation of performance issues. For example, in Scenario 1, the moral agent decides to capitalize repairs that should be journalized as revenue expenditures under generally accepted accounting principles (GAAP). In scenario 2, the moral agent reclassifies expenses from an internal capital budgeting project to normal operations, resulting in a falsely 
inflated project IRR. This study significantly contributes to the business and accounting ethics literature by assessing ethical dilemmas to provide empirical evidence about how managers would actually react to similar ethical conundrums in the workplace. Each base scenario has multiple treatments permitting detailed statistical analysis to assess influence on participants' ethical judgments and planned ethical actions.

In short, this study meaningfully contributes to the literature because, as Brown and Treviño (2006) note, there is a substantial literature that promulgates what managers should do in an ethical dilemma, but relatively little evidence about what managers would do when faced with ethical quandaries. This study attempts to fill this void by examining graduate students' perceptions of ethical judgments and ethical intentions in the face of ethical dilemmas, among other variables of interest.

\section{LITERATURE REVIEW, KEY VARIABLES, THEORY, AND HYPOTHESES DEVELOPMENT}

\section{Rest Model}

Jones et al. (2003) effectively recap the Rest (1979; 1986; 1994 - hereafter Rest Model) ethical reasoning process as a four component framework where one must 1) identify an ethical dilemma (ethical recognition), 2) make an ethical judgment about the ethical dilemma (ethical judgment), 3) create an intention to act ethically (ethical intention), and 4) act ethically (ethical behavior). Empirical research suggests the four components are generally, positively associated with each other, where ethical recognition $\Rightarrow$ ethical judgement $\Rightarrow$ ethical intentions $\Rightarrow$ ethical behavior (Jones et al. 2003; Johnson et al. 2012; Valentine, Fleischman, \& Godkin, 2018). Nevertheless, Jones (1991) clarifies that "each component in the process is conceptually distinct and that success in one stage does not imply success in any other stage" (p. 368). The majority of ethical reasoning studies that employ the Rest Model directly test stage two and stage three, which is the design strategy that we follow because these two stages focus on participants' assessment and reaction to the ethical dilemma posed. Furthermore, assessing Rest stage three permits one to generalize what participants' actual behavior would be based on their ethical intentions to act, given the strong correlation between intentions to act and actual behavior (Ajzen, 1985, 1991; Ajzen and Fishbien 1980).

\section{Dependent Variables}

Ethical Judgment

To measure ethical judgment, we use the first four items from the eight-item short version of the Multidimensional Ethics Scale (MES) derived from Reidenbach and Robin (1990). The MES, also scholarly endorsed by Thomason \& Brownlee (2018) in their research on ethical decision-making and psychological entitlement, refers to an individual's "personal ethical evaluation of a particular action, issue, or situation" (Robin, Reidenbach, and Babin 1997, p. 565). Reidenbach and Robin (1990) used standard scale development techniques to develop a scale that more parsimoniously measures three ethical dimensions. Flory et al. (1992) used this scale in a paper to ensure its validity. Loo (2004) also used the MES and concluded that it is psychometrically valid, as supported by Thomason \& Brownlee (2018). McMahon and Harvey (2007) compared the eight item short form and the 30-item pool of the MES and found tremendous support for the three-factor and five-factor forms of the instrument.

\section{Ethical Intentions}

To measure ethical intention, we use the scale from Barnett et al. 1996 that asks the participant to rate the probability that they would engage in the action themselves.

\section{Independent Variables}

Ethics Education

Loeb (1988) commented on teaching students accounting ethics shortly after the release of the Treadway Commission report that encouraged ethics education in the accounting curriculum. He advocated that a "classroom teaching accounting ethics may provide an accountant with confidence when approaching an ethical conflict situation." Ponemon and Glazer (1990) compared freshman, seniors and alumni from two schools: a large state university and a private liberal arts college. They found that freshman ethical 
reasoning was much the same between the schools, but that the seniors and alumni from the liberal arts college had statistically significantly higher ethical development than their counterparts from the large state university. They also compared their findings to prior research and found that only the seniors and alumni from the liberal arts college achieved ethical development scores equal to the adult population and college graduates in general. Abdolmohammadi and Ariail (2009) found that CPAs with a graduate degree have higher ethical awareness than those with only an undergraduate degree. These studies indicate that ethics education affects ethical development and awareness (Wang, \& Calvano, 2015). Interestingly, women may be somewhat less responsive to business ethics education than men (Wang, \& Calvano, 2015). Thus, we examine if an ethics capstone class and/or if ethics discussions in accounting classes lead to more effective ethical judgement and intentions to act.

Shawver and Miller (2017) ran an experiment and determined that ethics education improve perceptions of moral intensity which in turn had an impact on moral intent. That is, students reported less likelihood to complete unethical actions because they were able to recognize morally intense situations after receiving ethics training. The implications are that ethics education has a positive effect on ethical intentions and perceptions. This is reinforced by other scholars (Christensen, Cote, \& Latham, 2018; Wang \& Calvano, 2015). Previous research suggests that women are found to have higher ethical judgment and identify ethical issues better than do men (Schaub 1994; Ameen et al. 1996; Jones et al. 2003; Bernardi and Arnold 2004; Treviño et al. 2006), rely more heavily on deontological factors (Hunt and Vitell 2006), and tend to have higher intentions to act ethically (Valentine and Rittenberg 2007). Education (Jones et al. 2003) and religiosity (Emerson et al. 2006; Boone et al. 2013) generally increase ethical judgment and ethical intentions. Ethics education has become the norm in college programs during the past ten years. This practice is advocated by many sources (Fulmer and Cargile 1987; Loeb 1988; McPhail 2001) despite some conflicting findings. Some studies show that ethics education increases ethical judgment (Armstrong 1993; Schaub 1994; Douglas et al. 2001) while other studies show it does not (Ponemon 1993; Lowers et al. 1997). This research will investigate whether or not ethics education in college affects ethical decisionmaking. We hypothesize the following a priori relationship based on this literature.

H1a: There will be a positive and significant relationship between ethics education in classes and positive ethical judgment.

H1b: There will be a positive and significant relationship between ethics education in classes and ethical intentions.

\section{Moral Intensity}

Jones (1991) theorized that characteristics of the actual moral issue itself can impact ethical judgments as well as ethical intentions. Specifically, some ethical dilemmas are more highly, ethically charged than other dilemmas. In response, Jones (1991) created a moral intensity construct that accounts for ethical differences in business ethics situations while also capturing the issue contingent moral imperative nature of the dilemma. Salience and vividness will both increase moral intensity. According to Robin et al. (1996, p. 17), the construct "is personal and temporal in character in order to accommodate an individual's values, beliefs, needs, perceptions, the special characteristics of the situation, and the personal pressures existing on an ongoing basis or at a particular place and time." Moral intensity has six facets ${ }^{1}$ :

1. Magnitude of consequences, defined as the sum of the harm. An action that causes the greatest harm to the most people has the greatest magnitude and thus, will elicit greater effort during decision-making. If the harm doesn't meet some threshold, the agent may fail to recognize the moral issue at all.

2. Social consensus refers to the amount of good or evil the relevant society places upon the act; it also refers to the legality of the act.

3. Probability of effect refers to whether the act will happen or not and, if it does, whether the harm will actually occur. This probability is balanced against the magnitude of the gain. 
4. Temporal immediacy indicates that the consequences of the moral action will occur sooner rather than later, causing greater salience.

5. Proximity is the feeling of nearness either geographically, socially, culturally, or psychologically. If negative consequences will happen to those with whom we share greater proximity, we are less likely to develop unethical intent. The opposite of proximity is dispersion or distance.

6. Concentration of effect is an inverse function of the number of people affected by an act of given magnitude.

Many previous accounting ethics studies have looked at moral intensity (Morris and McDonald 1995; Singhapakdi et al. 1996; Shaub 1997; Wright, Cullinan and Bline 1997; Jones et al. 2003; Latan, Chiappetta Jabbour, \& Lopes de Sousa Jabbour, 2019; Leitsch 2004; Fleischman et al. 2010; Coram, Glavovic, Ng, and Woodliff 2008; Ng, White, Lee, and Moneta 2009).

We contend that moral intensity is a critical predictor variable for the present inquiry because morally intense situations become "the proving ground for ethical leadership" (Brown and Treviño 2006, p.602). Investigating moral intensity is important because it permits one to specifically identify which scenario issues participants perceive to be especially salient (Latan, Chiappetta Jabbour, \& Lopes de Sousa Jabbour, 2019). Brown and Treviño (2006, p. 602) describe further the following regarding moral intensity, in general, and the dimension of magnitude of consequences in particular.

[These concepts are] particularly important for ethical leadership because ethical leaders consider the consequences that their potential actions will have on others. When the potential for great harm exists, observers will pay attention to the decision maker to see how he or she handles the situation. When leaders face situations that have the potential to cause great harm and handle them in an ethically appropriate manner (as judged by followers), then the leader will be seen as an ethical leader. On the other hand, when leaders make decisions that bring significant harm to others, they will be seen as poor models of ethical behavior.

The literature indicates that the viewing an act as more intense on the moral intensity scale theoretically strengthens ethical judgments as well as ethical intentions (Brown and Treviño 2006; Fleischman et al. 2010; Jones 1991; Jones et al. 2003; Latan, Chiappetta Jabbour, \& Lopes de Sousa Jabbour, 2019). We hypothesize the following a priori relationship based on this literature.

H2a: There will be a positive and significant relationship between the perceived moral intensity of the issue and positive ethical judgment.

H2b: There will be a positive and significant relationship between the perceived moral intensity of the issue and ethical intentions.

Perceived Importance of an Ethical Issue (PIE)

Another key ethics construct augmenting moral intensity is PIE. The concept of PIE discovered by Robin et al. (1996). They contend that PIE enhances ethical judgment and ethical intention. Other studies also suggest that PIE impacts ethical judgments and intentions consistently (Cronan, Leonard, and Kreie 2005; Haines, Street, and Haines 2008; Valentine et al., 2018), much in the same manner as issue recognition. Therefore, we believe it is a key variable in this ethical dilemma study. We hypothesize the following a priori relationship based on this literature.

H3a: There will be a positive and significant relationship between the perceived importance of the issue and positive ethical judgment. 
$\boldsymbol{H} 3 \boldsymbol{b}$ : There will be a positive and significant relationship between the perceived importance of the issue and and ethical intentions.

Social Desirability Bias

Social desirability bias is usually a concern in ethics research (Dalton \& Ortegren, 2011; Randall and Fernandes, 1992; Cohen, Pant and Sharp 1996, 2001; Fleischman et al. 2007; 2010; Cohen, HolderWebb, Sharp, and Pant 2007; Johnson et al. 2012; Valentine, Hanson, \& Fleischman, 2018) because participants in ethically charged situations tend to present themselves in a socially desirable manner, meaning that they do not want to admit that they would act unethically whilst acknowledging gender differences (Dalton \& Ortegren, 2011). To measure this, we followed Cohen et al. (2007, p. 1126) by calculating social desirability as the difference between ethical intentions where participants were asked the probability that their peers would act the same as the vignette actor versus how the participant themselves would act using the same four-item, 7-point Likert ethical intentions scale (Barnett, Bass, and Brown 1996). Averages for each set are calculated and then the difference taken for a score consistent with Cohen et al. (2007). We hypothesize the following a priori relationship based on this literature.

H4a: There will be a positive and significant relationship between social desirability bias and positive ethical judgment, such that social desirability bias will moderately influence positive ethical judgment in a given scenario.

H4b: There will be a positive and significant relationship between social desirability bias and ethical intentions, such that social desirability bias will strongly influence ethical intentions in a given scenario.

\section{Teleological Ethical Orientation}

Teleological (consequences-based) and deontological (morality-based) evaluations of outcomes have been shown to influence ethical judgment and decision-making (Burns and Kiecker 1995; Hunt and Vitell 1986). Prior research finds that subordinate unethical accountingrelated behavior that happens to cause positive organizational consequences influences respondents acting as supervisors to temper their reprimands (or lack of support) for the otherwise unethical conduct of the subordinate (Burns and Kiecker 1995; Johnson et al. 2012) In other words, supervisor intentions to intervene became less extreme when the outcome was favorable rather than unfavorable to the organization. Although we measure both teleological and deontological leanings, we only hypothesize an a priori relationship with teleological leanings as follows.

H5a: Participants with a teleological leaning will show lower positive ethical judgment compared to the rest of the sample.

H5b: Participants with a teleological leaning will show fewer ethical intentions compared to the rest of the sample.

\section{Research Methodology and Experimental Procedures}

The study employs two base scenarios, shown in the Appendix, to manipulate the level of outcome favorability. We analyze the levels of favorable versus unfavorable personal outcomes. Scenario 1 focuses on an assistant controller, Oakley Williams, who initially authorized repairs deemed essential to enhancing operational efficiency in order to entice a large new client. However, because of transaction complications and delays, the firm was unable to obtain the new business as fast as it would have liked, resulting in disappointing first quarter results. Unfortunately, the poor financial performance triggered by the additional repairs will cause the company to fall out of compliance with debt covenants, which will necessitate additional collateral that will be difficult to provide. Due to these pressures from the bank, and given that Williams wants to apply for the vacant controller position, Williams decides to capitalize the expenses instead of correctly recording them as revenue expenditures. 
This reclassification helps the firm avoid debt covenant noncompliance. This scenario has a 1 X 2 randomized design manipulating favorable versus unfavorable personal outcomes. Scenario 2 features Casey Miller, one of three senior managers submitting internal proposals for potential capital budget funding. Only one manager is selected each year to receive funding up to one million dollars. The last three managers that won the bid and completed their projects successfully were promoted to vice president and given very handsome salary increases. At the end of the cost analysis, Miller realizes that the project's proposed IRR is estimated to come in at 7.5\%, while every project approved in the last few years had an $8 \%$ IRR or higher. Smith realizes reclassifying one project expenditure as a normal operating expense instead of a project expense will adjust the projected IRR upwards to $8.15 \%$.

This higher IRR will improve the likelihood of getting the funding, and the cost reclassification to operations is unlikely to be discovered. The second scenario assesses participant perceptions related to a reclassification that does not result in a very large upward adjustment in IRR.

\section{Sample, Demographics, Sampling Strategy, and Data Collection}

The final sample for the current study includes 156 graduate students at a large southeastern university, many of whom possess substantial prior work experience. The survey deals with questions involving MA decision-making and ethical situations. Students entered into a drawing for a cash prize for their voluntary participation in this investigation ${ }^{2}$. The survey instruments and scales present in this study (previously validated questionnaires - see Appendix A) are validated and vetted using appropriate research techniques and scholarly recommendations, thereby minimizing concerns related with validity, internal consistency, and reliability (Law, 2011). Cronbach's alphas are found to be supportive and consistent with the required measures $(\alpha=.615$ for CEV; $\alpha=.765$ for DEON; $\alpha=.726$ for LOC; $\alpha=.618$ for TELEO; $\alpha=.753$ for POL).

Demographics of the study indicate that the average age of all the survey participants is 23.5 years. In terms of age breakdown, the sample consists of participants between the ages of 21 and 46. The academic background of the sample (mostly equally widespread across the entire sample), from a major concentration standpoint, includes accounting, human resources management, finance and economics, general management, business informatics, financial management, business administration, entrepreneurship, marketing, business analytics, with minors in music, theatre, planning, international dance, urban planning, agriculture, and some others not specified in detail. Over $90 \%$ of the respondents report that they are single, with less than $10 \%$ married. The majority of the sample consists of students who have previously taken a course specifically targeted to ethics or having a concentration in ethics. Participants are predominantly White or Caucasian (80\%) with less than $20 \%$ representing other races, including Black, Asian, Indian, and others. Finally, seven students were randomly selected as the survey drawing winners for the $\$ 25$ cash prize.

\section{Data Analysis}

The study employs General Linear Modeling (GLM) MANCOVA regression because this multivariate statistical method efficiently assesses correlated dependent variables, consistent with previous research in accounting (Fleischman and Stephenson 2012; Johnson et al. 2012). MANCOVA permits us to statistically assess the impact of our predictor variables on our two correlated dependent variables simultaneously. Furthermore, MANCOVA is appropriate when there is a mix of nonmetric categorical predictor variables (coded as fixed factors), combined with metric ordinal or continuous variables (coded as covariates). Fleischman and Stephenson (2012, p. 426, footnote 7) highlight that MANCOVA is especially efficient in minimizing type 1 errors while also increasing the likelihood of finding significant predictor variable associations as compared with univariate assessment. MANCOVA regression addresses how moral intensity influences ethical judgements as well as ethical intentions.

We also use independent samples $t$ tests with correction for unequal variances to investigate the interplay between ethical (unethical) behavioral treatments with favorable (unfavorable) consequence treatments on moral intensity. Independent sample $t$ tests also assess treatment interplay to identify the moderating influence on ethical judgments and ethical intentions. 


\section{FINDINGS, RESULTS, INTERPRETATIONS, AND DISCUSSION}

Our study uses graduate students from a large southeastern university, many of whom work or have worked in management. One additional purpose of this study is to determine if there are statistical differences between the vignettes used for the study and if the variables of interest are significantly correlated with our dependent variables (ethical judgment and ethical intention). Running two-sample ttests between each version of the two vignettes and between the related treatments shows some statistically significant results.

We employ GLM MANCOVA regression to determine the significance of predictor variables. Because all predictor variables must be significant in the multivariate model, we removed any variables that were not significant. Table 1 displays the results of the analysisreduced model. Our results show that having teleological leanings and greater PIE are strongly associated with ethical judgment. Additionally, greater moral intensity is weakly associated with ethical judgment. Our participants show nominal social desirability bias when exercising ethical judgment, but a great deal of this bias when indicating an ethical intention. Moral intensity is also moderately associated with ethical intention. Discussing ethics in a greater percentage of accounting classes does not significantly impact ethical judgement, but it does moderately affect ethical intention. Finally, both teleological leanings and greater PIE are weakly associated with ethical intention. Therefore, we find strong support for all four of our hypotheses, such that H1, H2, H3, and $\mathrm{H} 4$ are supported.

\section{CONCLUSION}

Consistent with prior supportive research (Burns and Kiecker 1995; Hunt and Vitell 1986), we demonstrate that ethical orientation (teleological vs deontological) has a strong impact on the ethical judgment and intentions of people, and eventually, on the ethical decision-making of individuals. We find teleological leanings, in terms of consequentialism outcomes (both favorable and unfavorable, as well as, both ethical and unethical), affect individual judgments and likely cause serious organizational consequences as well.

The paper investigates the ethical dilemmas involving large versus small MA cost reclassifications while incorporating tremendous job-related stressors and pressures on the moral actor in order to see if the magnitude of the issue influences individual ethical intention and judgment. Of interest is the finding that increased perceptions of the importance of ethical issues and concerns strongly influence individual ethical and moral judgments and reasoning. Our approach differs from the majority of the ethics literature and research in business which is on Kohlberg's Theory of Moral Development (Kohlberg, 1976).

A number of forces and pressures, both within and outside of organizations in various contexts continue to impact ethical issue recognition, moral reasoning/ judgment of individuals, and their overall ethical decision-making process and behaviors. Surprisingly, moral intensity does not demonstrate a considerable effect on the ethical reasoning and judgments of individuals in our study. This finding supports past research by Jones (1991), such that, scholars in years past have acknowledged that some ethical situations and conundrums might be, either ethically or unethically, less stimulating than others, thereby summarizing the ethical import of current research.

Where some concerns over social desirability bias are present in this study, these pointscan be addressed in future studies using the third-person framing technique as suggested by some scholars (Jensen \& Hurley, 2005). Otherwise, this study is highly generalizable, and we consider it to be a major contribution to the literature and research in business ethics, accounting, management, corporate governance, and finance.

\section{ACKNOWLEDGEMENTS}

We'd like to thank the workshop participants at the University of Oregon, the University of Northern Iowa, Western Kentucky University, Central Washington University, the University of South Dakota, the Western Regional Meetings of the AAA, and the Ethics Consortiums, as well as Gary M. Fleischman, 
William F. Miller, Matthew Sooy, Ross Taplin, and Thomas Tiahrt for their invaluable comments, suggestions, feedback, and advice.

\section{ENDNOTES}

1. These are quoted and/or paraphrased from Jones 1991 pages 374-378.

2. There was one $\$ 25$ cash prize for each increment of 25 participants giving each person at least a four percent chance of winning the cash prize. In total, seven $\$ 25$ cash prizes were awarded.

\section{REFERENCES}

Abdolmohammadi, M.J., \& Ariail, D.L. (2009). A Test of the Selection-Socialization Theory in Moral Reasoning of CPAs in Industry Practice. Behavioral Research in Accounting, 21(2), 1-12.

Ajzen, I., \& Fishbien, M. (1980). Understanding Attitudes and Predicting Social Behavior. Englewood Cliffs, NJ: Prentice-Hall Publishers.

Allport, G.W., \& Ross, J.M. (1967). Personal religious orientation and prejudice. Journal of Personality and Social Psychology, 5, 432-43.

Ambrose, M.L., \& Kulik, C. (1999). Old friends, new faces: Motivation research in the 1990's. Journal of Management, 25, 231-292.

Ameen, E.C., Guffey, D.M., \& McMillan, J.J. (1996). Gender Differences in Determining the Ethical Sensitivity of Future Accounting Professionals. Journal of Business Ethics, 15, 591-597.

Armstrong, M.B. (1987). Moral Development in Accounting Education. Journal of Accounting Education, 5, 27-43.

Armstrong, M.B. (1993). Ethics and Professionalism in Accounting Education: A Sample Course. Journal of Accounting Education, 11, 77-92.

Barnett, T., Bass, K., \& Brown, G. (1996). Religiosity, ethical ideology, and intentions to report a peer's wrongdoing. Journal of Business Ethics, 15(11), 1161-1174.

Barnett, T., \& Valentine, S. (2004). Issue contingencies and marketers' recognition of ethical issues, ethical judgments and behavioral intentions. Journal of Business Research, 57, 338-346.

Bay, D. (2002). A Critical Evaluation of the Use of The DIT in Accounting Ethics Research. Critical Perspectives on Accounting, 13, 159-177.

Bernardi, R.A., \& Arnold, D.F., Sr. (2004). Testing the "Inverted-U" Phenomenon in Moral Development on Recently Promoted Senior Managers and Partners. Contemporary Accounting Research, 21(2), 353-67.

Beu, D., \& Buckley, M.R. (2001). The Hypothesized Relationship between Accountability and Ethical Behavior. Journal of Business Ethics, 34, 57-73.

Boone, J.P., Khurana, I.K., \& Raman, K.K. (2013, Spring). Religiosity and Tax Avoidance. The Journal of the American Taxation Association, 35(1), 53-84.

Brown, M.E., \& Treviño, L.K. (2006). Ethical leadership: A review and future directions. The Leadership Quarterly, 17, 595-616.

Burns, J.O., \& Kiecker, P. (1995, Fall). Tax Practitioner Ethics: An Empirical Investigation of Organizational Consequences. Journal of the American Taxation Association, 17(2), 20-49.

Carney, D.R., Jost, J.T., Gosling, S.D., \& Potter, J. (2008). The Secret Lives of Liberal and Conservatives: Personality Profiles, Interaction Styles, and the Things They Leave Behind. Political Psychology, 29(6), 807-839.

Chow, C., Cooper, J., \& Waller, W. (1988). Participative budgeting: Effects of a truth-inducing pay scheme and information asymmetry on slack and performance. The Accounting Review, 63, 111-122.

Christensen, A., Cote, J., \& Latham, C.K. (2018). Developing ethical confidence: The impact of actionoriented ethics instruction in an accounting curriculum. Journal of Business Ethics, 153(4), 1157 1175. 
Cogliser, C.C., Gardner, W.L., Gavin, M.B., \& Broberg, J.C. (2012). Big Five Personality Factors and Leader Emergence in Virtual Teams: Relationships With Team Trustworthiness, Member Performance Contributions, and Team Performance. Group \& Organization Management, 37(6), $752-784$.

Cohen, J.R., Holder-Webb, L., Sharp, D.J., \& Pant, L.W. (2007). The effects of perceived fairness on opportunistic behavior. Contemporary Accounting Research, 24(4), 1119-1138.

Cohen, J.R., Pant, L.W., \& Sharp, D.J. (1996). Measuring the ethical awareness and ethical orientation of Canadian auditors. Behavioral Research in Accounting, 8(Supplement), 98119.

Cohen, J.R., Pant, L.W., \& Sharp, D.J. (2001). An examination of differences in ethical decision-making between Canadian business students and accounting professionals. Journal of Business Ethics, 30(4), 319-336.

Coram, P., Glavovic, A., Ng, J., \& Woodliff, D.R. (2008). The moral intensity of reduced audit quality acts. Auditing: A Journal of Practice \& Theory, 27(1), 127-149.

Cronan, T.P., Leonard, L.N.K., \& Kreie, J. (2005). An empirical validation of perceived importance and behavioral intention in IT ethics. Journal of Business Ethics, 56(3), 231-238.

Cruz, C.A., Shafer, W.E., \& Strawser, J.R. (2000). A Multidimensional Analysis of Tax Practitioners' Ethical Judgments. Journal of Business Ethics, 24, 223-244.

Dalton, D., \& Ortegren, M. (2011). Gender differences in ethics research: The importance of controlling for the social desirability response bias. Journal of Business Ethics, 103(1), 73-93.

Daumoser, C., Hirsch, B., \& Sohn, M. (2018). Honesty in budgeting: A review of morality and control aspects in the budgetary slack literature. Journal of Management Control, 29(2), 115-159.

Davis, S., DeZoort, F., \& Kopp, L. (2006). The effect of obedience pressure and perceived responsibility on management accountants' creation of budgetary slack. Behavioral Research in Accounting, 18, $19-35$.

DeConinck, J.B., \& Lewis, W.F. (1997). The Influence of Deontological and Teleological Considerations, and Ethical Climate on Sales Managers' Intentions to Reward or Punish Sales Force Behavior. Journal of Business Ethics, 16, 497-506.

Douglas, P., \& Wier, B. (2000). Integrating ethical dimensions into a model of budgetary slack creation. Journal of Business Ethics, 28, 267-277.

Douglas, P.C., Davidson, R.A., \& Schwartz, B.N. (2001). The Effect of Organizational Culture and Ethical Orientation on Accountants' Ethical Judgments.

Egan, M. (2016). 5,300 Wells Fargo employees fired over 2 million phony accounts. Retrieved April 24, 2017, from http://money.cnn.com/2016/09/08/investing/wells-fargo-created-phony-accountsbankfees/

Emerson, T.L.M., Conroy, S.J., \& Stanley, C.W. (2007). Ethical Attitudes of Accountants: Recent Evidence from a Practitioners' Survey. Journal of Business Ethics, 71, 73-87.

Etherington, L.D., \& Hill, N.T. (1998). Ethical Development of CMAs: A Focus on Non-Public Accountants in the United States. Research on Accounting Ethics, 4, 225-245.

Fehr, R., Yam, K.C., \& Dang, C. (2015). Moralized leadership: The construction and consequences of ethical leader perceptions. Academy of Management Review, 40(2), 182-209.

Fleischman, G.M., \& Stephenson, T.M. (2012). Client variables associated with four key determinants of demand for tax preparer services: An exploratory model. Accounting Horizons, 26(3), 417-437.

Fleischman, G.M., Valentine, S.R., \& Finn, D.W. (2007). Ethical reasoning and equitable relief. Behavioral Research in Accounting, 19, 107-132.

Fleischman, G.M., Valentine, S.R., \& Finn, D.W. (2010). Moral intensity, ethical reasoning, and equitable relief judgments. Research on Professional Responsibility and Ethics in Accounting, 14, 79-112.

Flory, S.M., Phillips, T.J., Jr., Reidenbach, R.E., \& Robin, D.P. (1992). A Multidimensional Analysis of Selected Ethical Issues in Accounting. The Accounting Review, 67(2), 284-302.

Ford, R.C., \& Richardson, W.D. (1994). Ethical Decision-Making: A Review of the Empirical Literature. Journal of Business Ethics, 13, 205-221. 
Ford, M.R., \& Lowery, C.R. (1986). Gender differences in moral reasoning: A comparison of the use of justice and care orientations. Journal of Personality and Social Psychology, 50(4), 777.

Fulmer, W.E., \& Cargile, B.R. (1987, Spring). Ethical Perceptions of Accounting Students: Does Exposure to a Code of Professional Ethics Help. Issues in Accounting Education, pp. 207-219.

Gilligan, C. (1982). In a Different Voice. Cambridge, MA: Harvard University Press.

Haines, R., Street, M.C., \& Haines, D. (2008). The influence of perceived importance of an ethical issue on moral judgment, moral obligation, and moral intent. Journal of Business Ethics, 81(2), 387399.

Healy, P. (1985). The effect of bonus schemes on accounting decisions. Journal of Accounting and Economics, 7, 85-107.

Hope, J., \& Fraser, R. (1997). Beyond budgeting. Management Accounting: Magazine for Chartered Management Accountants, 75, 20-23.

Hope, J., \& Fraser, R. (2000). Beyond Budgeting. Strategic Finance, 82, 30-35.

Hope, J., \& Fraser, R. (2003). News ways of setting rewards: The beyond budgeting model. California Management Review, 45, 104-119.

Hunt, S.D., \& Vitell, S.J. (1986). A General Theory of Marketing Ethics. Journal of Macromarketing, $6(1), 5-16$.

Hunt, S.D., \& Vitell, S.J. (2006). A General Theory of Marketing Ethics: A Revision and Three Questions. Journal of Macromarketing, 26, 143-153.

Jensen, J.D., \& Hurley, R.J. (2005). Third-person effects and the environment: Social distance, social desirability, and presumed behavior. Journal of Communication, 55(2), 242-256.

Jensen, M. (2001). Corporate budgeting is broken - let's fix it. Harvard Business Review, 79(11), 95-101.

Jensen, M. (2003). Paying people to lie: The truth about the budgeting process. European Financial Management, 9, 379-406.

Jennergren, L. (1980). On the design of incentives in business firms: A survey of some research. Management Science, pp. 180-201.

Johnson, E.N., Fleischman, G.M., Valentine, S.R., \& Walker, K.B. (2012). Managers' ethical evaluations of earnings management and its consequences. Contemporary Accounting Research, 29(3), 910927.

Jones, J., Massey, D.W., \& Thorne, L. (2003). Auditors' Ethical Reasoning: Insights from Past Research and Implications for the Future. Journal of Accounting Literature, 22, 45-103.

Jones, T.M. (1991). Ethical Decision Making by Individuals in Organizations: An Issue Contingent Model. Academy of Management Review, pp. 366-395.

Judge, T.A., Bono, J.E., Ilies, R., \& Gerhardt, M.W. (2002). Personality and leadership: A qualitative and quantitative review. Journal of Applied Psychology, 87(4), 765.

Kohlberg, L. (1976). Moral stages and moralization: The cognitive-development approach. In T. Lickona (Ed.), Moral Development and behavior: Theory, research and social issues (pp. 31-53). New York: Holt, Rinehart \& Winston.

Kohn, A. (1993). Why incentive plans cannot work. Harvard Business Review, 71(5), 54-63.

Latan, H., Chiappetta Jabbour, C. J., \& Lopes De Sousa Jabbour, A. B. (2017). Ethical Awareness, Ethical Judgment and Whistleblowing: A Moderated Mediation Analysis. Journal of Business Ethics, 155(1), 289-304. https://doi.org/10.1007/s10551-017-3534-2

Law, P. (2011). Corporate governance and no fraud occurrence in organizations: Hong Kong evidence. Managerial Auditing Journal, 26(6), 501-518.

Leitsch, D.L. (2004). Differences in the Perceptions of Moral Intensity in the Moral Decision Process: An Empirical Examination of Accounting. Journal of Business Ethics, 53, 313-323.

Locke, E., \& Latham, G. (1990). A Theory of Goal Setting and Task Performance. Englewood Cliffs, NJ: Prentice-Hall.

Locke, E.A., \& Latham, G.P. (2019). The development of goal setting theory: A half century retrospective. Motivation Science, 5(2), 93. 
Loeb, S.E. (1988). Teaching Students Accounting Ethics: Some Crucial Issues. Issues in Accounting Education, 3, 316-329.

Loo, R. (2004). Support for Reidenbach and Robin's (1990) eight-item multidimensional ethics scale. The Social Science Journal, 41, 289-294.

Lowers, T., Ponemon, L., \& Radtke, R. (1997). Examining accountants' ethical behavior: A review and implications for future research. In V. Arnold \& S. Sutton (Eds.), Behavioral Accounting Research: Foundations and Frontiers (pp. 188-221). Sarasota, FL: AAA.

Luft, J., \& Shields, M. (2003). Mapping management accounting: Graphics and guidelines for theoryconsistent empirical research. Accounting, Organizations and Society, 28(3), 169-249.

Luft, J., \& Shields, M. (2014). Subjectivity in developing and validating causal explanations in positivist accounting research. Accounting, Organizations and Society, 39(7), 550-558.

Lunenburg, F.C. (2011). Goal-setting theory of motivation. International Journal of Management, Business, and Administration, 15(1), 1-6.

McMahon, J.M., \& Harvey, R.J. (2007). Psychometric Properties of the Reidenbach Robin Multidimensional Ethics Scale. Journal of Business Ethics, 72, 27-39.

McNabb, R., \& Whitfield, K. (2007). The impact of varying types of performance-related pay and employee participation on earnings. International Journal of Human Resource Management, 18(6), 1004-1025.

McPhail, K. (2001). The other objective of ethics education: Re-humanising the accounting profession-A study of ethics education in law, engineering, medicine and accountancy. Journal of Business Ethics, 34(3-4), 279-298.

Miller, Y., Kark, R., \& Zohar, N. (2019). Her/his ethics? Managerial ethics in moral decisionmaking from a contextual, gendered, and relational perspective. Sex Roles, 80(3-4), 218233.

Mitchell, M.S., Baer, M.D., Ambrose, M.L., Folger, R., \& Palmer, N.F. (2018). Cheating under pressure: A self-protection model of workplace cheating behavior. Journal of Applied Psychology, 103(1), 54.

Morris, S.A., \& McDonald, R.A. (1995). The Role of Moral Intensity in Moral Judgments: An Empirical Investigation. Journal of Business Ethics, 14, 715-726.

$\mathrm{Ng}$, J., White, G.P., Lee, A., \& Moneta, A. (2009). Design and validation of a novel new instrument for measuring the effect of moral intensity on accountants' propensity to manage earnings. Journal of Business Ethics, 84(3), 367-387.

Ordonez, L., Schweitzer, M., Galinsky A., \& Bazerman, M. (2009). Goals gone wild: The systematic side effects of overprescribing goal setting. Academy of Management Perspectives, pp. 7-16.

Pan, Y., \& Sparks, J.R. (2012). Predictors, consequence, and measurement of ethical judgments: Review and meta-analysis. Journal of Business Research, 65, 84-91.

Pfeffer, J. (1998). Six dangerous myths about pay. Harvard Business Review, 76(3), 108-119.

Plunkett, L., \& Rouse. R. (n.d.). Revenue recognition and the Bausch and Lomb case. CPA Journal, 68(9), 54-56.

Ponemon, L.A. (1993). Can Ethics Be Taught in Accounting? Journal of Accounting Education, 11, 185209.

Ponemon, L., \& Glaze, A. (1990). Accounting Education and Ethical Development: The Influence of Liberal Learning on Students and Alumni in Accounting Practice. Issues in Accounting Education, 5(2), 195-208.

Randall, M.F., \& Fernandes, D.M. (1992). Social desirability bias in ethics research. Business Ethics Quarterly, 2(2), 183-205.

Reidenbach, R.E., \& Robin, D.P. (1990). Toward the Development of a Multidimensional Scale for Improving Evaluations of Business Ethics. Journal of Business Ethics, 9, 639-653.

Reiter, S.A. (1996). The Kohlberg - Gilligan Controversy: Lessons for Accounting Ethics Education. Critical Perspectives on Accounting, 7, 33-54.

Rest, J.R. (1979). Development in Judging Moral Issues. Minneapolis, MN: University of Minnesota Press.

70 Journal of Leadership Accountability, and Ethics Vol. 18(5) 2021 
Rest, J.R. (1986). Moral development: Advances in Research and Theory. New York: Praeger Press.

Rest, J.R. (1994). Background theory and research. In J.R. Rest \& D. Narvaez (Eds.), Moral Development in the Professions (pp. 1-26). Hillsdale, NJ: Lawrence Erlbaum Associates.

Schweitzer, M., Ordonez, L., \& Douma, B. (2004). Goals setting as a motivator of unethical behavior. Academy of Management Journal, 47, 422-432.

Robin, D.P., Reidenbach, R.E., \& Forrest, P.J. (1996). The perceived Importance of an ethical issue as an influence on the ethical decision-making of ad managers. Journal of Business Research, $35(1), 17-28$.

Shaub, M.K. (1994). Analysis of the Association of Traditional Demographic Variables with the Moral Reasoning of Auditing Students and Auditors. Journal of Accounting Education, 12(1), 1-26.

Shaub, M.K. (1997). Commentary on the Relationship between an Individual's Values and Perceptions of Moral Intensity: An Empirical Study. Behavioral Research in Accounting, 9(Supplement).

Shawver, T.J., \& Miller, W.F. (2017). Moral Intensity Revisited: Measuring the Benefit of Accounting Ethics Interventions. Journal of Business Ethics, 141, 587-603.

Singhapakdi, A., Vitell, S.J., \& Kraft, K.L. (1996). Moral Intensity and Ethical Decision-Making of Marketing Professionals. Journal of Business Research, 36, 245-255.

Smith, K.B., Alford, J.R., Hibbing, J.R., Martin, N.G., \& Hatemi, P.K. (2017). Intuitive ethics and political orientations: Testing moral foundations as a theory of political ideology. American Journal of Political Science, 61(2), 424-437.

St. Pierre, K.E., Nelson, E.S., \& Gabbin, A.L. (1990). A Study of the Ethical Development of Accounting Majors in Relation to Other Business and Nonbusiness Disciplines. The Accounting Educators' Journal, pp. 23-35.

Thomason, S., \& Brownlee, A. (2018). Ethical Decision Making and Psychological Entitlement. Business and Society Review, 123(4), 631-659.

Thorne, L. (2000). The Development of Two Measures to Assess Accountants' Prescriptive and Deliberative Moral Reasoning. Behavioral Research in Accounting, 12, 139-169.

Treviño, L.K. (1986). Ethical decision making in organizations: A person-situation interactionist model. Academy of Management Review, 11, 601-617.

Treviño, L.K., Weaver, J.R., \& Reynolds, S.J. (2006). Behavioral Ethics in Organizations: A Review. Journal of Management, 32, 951-990.

Tsui Judy, S.L., \& Gul, F.A. (1996). Auditors' Behavior in an Audit Conflict Situation: A Research Note on the Role of Locus of Control and Ethical Reasoning. Accounting, Organizations and Society, 21(1), 41-51.

Valentine, S., Fleischman, G., \& Godkin, L. (2016). Villains, Victims, and Verisimilitudes: An Exploratory Study of Unethical Corporate Values, Bullying Experiences, Psychopathy, and Selling Professionals' Ethical Reasoning. Journal of Business Ethics, 148(1), 135-154. https://doi.org/10.1007/s10551-015-2993-6

Valentine, S.R., Hanson, S.K., \& Fleischman, G.M. (2018). The presence of ethics codes and employees' internal locus of control, social aversion/malevolence, and ethical judgment of incivility: A study of smaller organizations. Journal of Business Ethics, pp. 1-18.

Valentine, S., \& Godkin, L. (2019). Moral intensity, ethical decision making, and whistleblowing. Intention. Journal of Business Research, 98, 277-288.

Valentine, S.R., \& Rittenberg, T.L. (2007). The Ethical Decision-Making of Men and Women Executives in International Business Situations. Journal of Business Ethics, 71, 125-134.

Walker, A.G., Smither, J., \& DeBode, J. (2012). The Effects of Religiosity on Ethical Judgments. Journal of Business Ethics, 106, 437-452.

Wang, L.C., \& Calvano, L. (2015). Is business ethics education effective? An analysis of gender, personal ethical perspectives, and moral judgment. Journal of Business Ethics, 126(4), 591-602.

Welsh, D.T., \& Ordóñez, L.D. (2014). The dark side of consecutive high performance goals: Linking goal setting, depletion, and unethical behavior. Organizational Behavior and Human Decision Processes, 123(2), 79-89. 
Wright, G.B., Cullinan, C.P., \& Bline, D.M. (1997). The Relationship Between an Individual's Values and Perceptions of Moral Intensity: An Empirical Study. Behavioral Research in Accounting, 9(Supplement), 26-40.

Young, S. (1985). Participative budgeting: The effects of risk aversion and asymmetric information on budgetary slack. Journal of Accounting Research, 23, 829-842.

Zaal, R.O., Jeurissen, R.J., \& Groenland, E.A. (2019). Organizational architecture, ethical culture, and perceived unethical behavior towards customers: Evidence from wholesale banking. Journal of Business Ethics, 158(3), 825-848.

\section{APPENDIX A}

TABLE 1

UNIVARIATE ANALYSIS OF COVARIANCE (ANCOVA)

Panel A: Dependent Measure $=$ Ethical Judgment $\left(\right.$ adjusted $\left.\mathrm{R}^{2}=.465\right)$

\begin{tabular}{lccccc}
\hline Source & MS & \multicolumn{2}{c}{ F } & Partial $\eta^{2}$ & Power \\
\hline Corrected Model & 24.917 & 20.411 & $* * *$ & .489 & 1.000 \\
Intercept & 13.870 & 11.362 & $* * *$ & .082 & .917 \\
Moral Intensity & 4.033 & 3.304 & $\wedge$ & .025 & .438 \\
Social Desirability & 1.012 & .829 & & .829 & .148 \\
Teleological & 14.330 & 11.739 & $* * *$ & .084 & .925 \\
PIE & & & & .236 & 1.000 \\
Ethics Classes & 48.165 & 39.455 & $* * *$ & .010 & .210 \\
Treatment & 1.640 & 1.344 & & .026 & .447 \\
\hline
\end{tabular}

72 Journal of Leadership Accountability, and Ethics Vol. 18(5) 2021 
Panel B: Dependent Measure $=$ Ethical Intention (adjusted $\left.\mathrm{R}^{2}=.322\right)$

\begin{tabular}{|c|c|c|c|c|c|}
\hline Source & MS & $\mathrm{F}$ & & Partial $\eta^{2}$ & Power \\
\hline Corrected Model & 12.822 & 11.623 & $* * *$ & .353 & 1.000 \\
\hline Intercept & 13.736 & 12.450 & $* * *$ & .089 & .938 \\
\hline Moral Intensity & 9.022 & 8.178 & $* *$ & .060 & .810 \\
\hline Social Desirability & 13.274 & 12.032 & $* * *$ & .086 & .931 \\
\hline Teleological & 3.529 & 3.199 & $\wedge$ & .024 & .427 \\
\hline PIE & 3.233 & 2.930 & $\wedge$ & .022 & .397 \\
\hline Ethics Classes & 4.475 & 4.057 & $*$ & .031 & .516 \\
\hline Treatment & .927 & .840 & & .007 & .149 \\
\hline
\end{tabular}

\section{APPENDIX B: SURVEY MATERIALS SCENARIO 1: (MANAGER-IMPROPER JOURNAL ENTRIES)}

FSW's assistant controller, Oakley Williams, authorized repairs necessary to enhance the efficiency of operations to entice a large new client to move its business to FSW. Oakley knew that the new business resulting from the client would offset the cost of repairs. Unfortunately, complications delayed the transition, and disappointing first quarter results were in. The shareholders and managers would be upset, of course, but the real problem was National Bank. The loan covenants were out of compliance due to the increased expenses; thus, additional collateral would be required and a large payment would have to be paid. Oakley wasn't sure what assets were available for collateral, but was sure that free cash flow wasn't sufficient for the payment. Oakley, up for promotion to the vacant controller position, knew the repairs started a chain of events that might seriously jeopardize the promotion. Oakley scanned the records again and realized that a simple journal entry reclassifying one of the repairs as an asset would put the quarterly results on target and prevent issues with the loan covenants. Next quarter, when the new business comes in, that entry can be reversed and the overall results for the first half of the year will be accurate.

\section{Unethical-Favorable (Treatment 1B)}

After thinking the situation through, Oakley decided to make the journal entry. The next quarter the client was brought onboard, the journal entry reversed and the quarterly results were as anticipated. FSW's CEO, impressed with how Oakley handled the situation, approved the promotion to controller and a pay raise.

\section{Unethical-Unfavorable (Treatment 1D)}

After thinking the situation through, Oakley decided to make the journal entry. The next quarter the client was brought onboard, the journal entry reversed and the quarterly results were as anticipated. However, Oakley's colleague informed the CEO of Oakley's actions. FSW's CEO, distressed with how Oakley handled the situation, issued a reprimand and removed Oakley's name from the pool of candidates for controller. 


\section{SCENARIO 2: (Manager-Improper Estimates/Capital Budgeting/Small Variance)}

Casey Miller is one of three senior managers submitting internal proposals for a capital budgeting project. Only one manager is selected each year to receive funding that can reach up to one million dollars. The last three managers that won the bid were promoted to vice president and given very handsome salary increases. Casey asked each member of the department to gather information on projected costs and revenue, and was assembling the pieces into a final project budget. At the end of the analysis, Casey stared at the computer in disbelief. The Internal Rate of Return (IRR) was estimated to come in at $7.5 \%$, but every project approved in the last few years had an $8 \%$ IRR or higher. Casey examined the numbers for a long time and realized that by reclassifying one project expenditure as a normal operating expense instead of a project expense, the projected IRR could be adjusted upwards to $8.15 \%$. Casey knew the higher IRR would improve the likelihood of getting the funding and the cost reclassification to operations was unlikely to be discovered.

\section{SCENARIO 2A - IRR Small Change; Personal; Unethical/Not Fixed/Favorable}

Casey decided to turn in the proposal based on the higher projected IRR due to the cost reclassification. The project was funded and, when completed, the IRR came in at $8 \%$. No one noticed the added expenditure that had been reclassified to normal operations, thus understating operating income. One year later Casey was promoted to vice president.

\section{SCENARIO 2B IRR Small Change; Personal; Unethical/Discovered/Unfavorable}

Casey decided to turn in the proposal based on the higher projected IRR due to the cost reclassification. The project was funded and, when completed, the IRR came in at $8 \%$. During the annual audit a few months later, the project expenditure that had been reclassified to normal operations was discovered and reassigned to the project. The IRR for the project was recalculated to be $7.4 \%$. Casey was not promoted.

\section{SCENARIO 2C IRR Small Change; Personal; Unethical/Good Results-Fixed/Favorable}

Casey decided to turn in the proposal based on the higher projected IRR due to the cost reclassification. The project was funded and, when completed, the IRR came in much higher than expected. Casey was able to reverse the reclassification by reinstating the omitted expenditure back to the project rather than normal operations and still achieve an IRR of $8 \%$ on the project. One year later Casey was promoted to vice president. 


\section{RESEARCH MODEL}

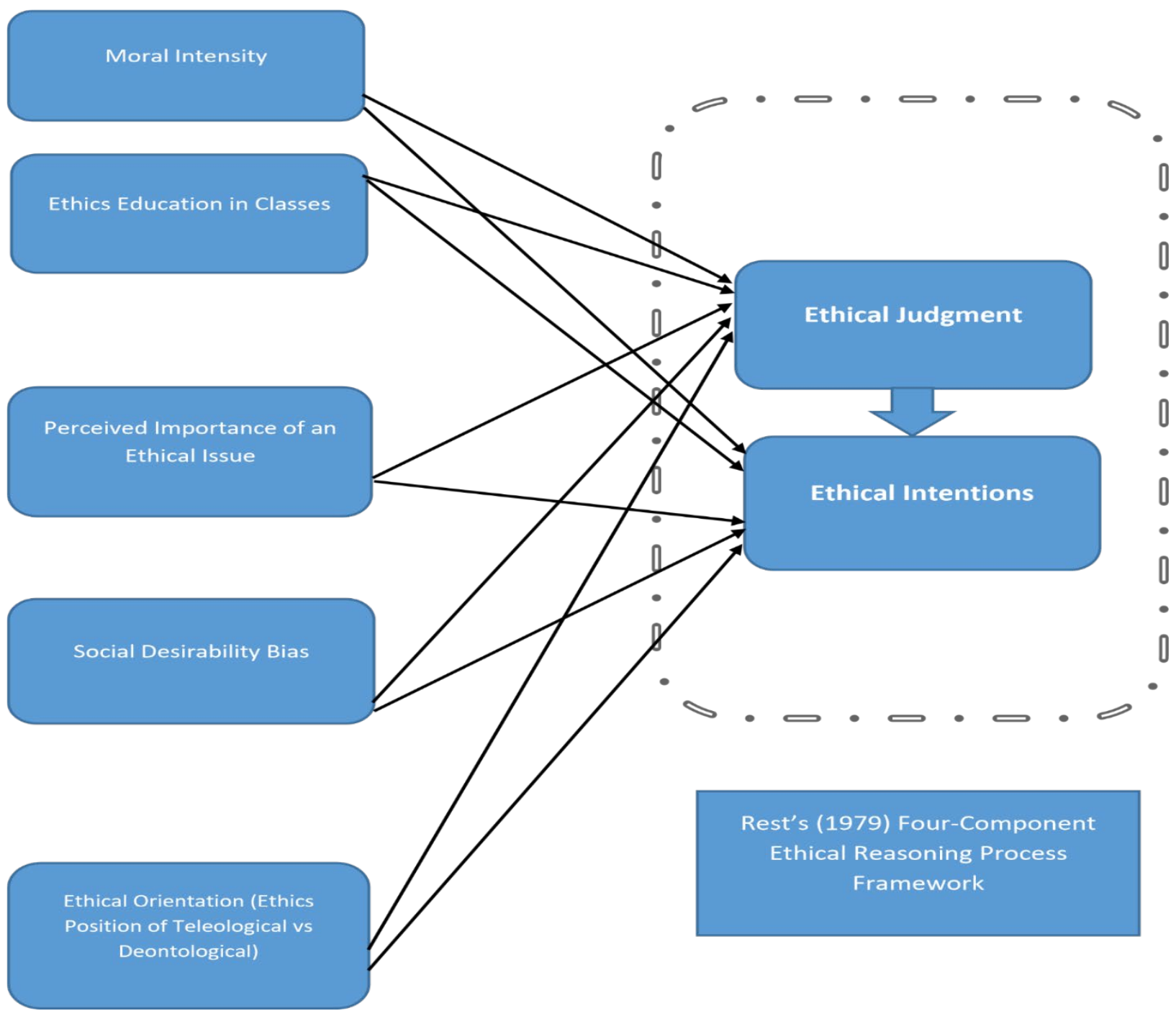

